\title{
HIV/AIDS IS REDUCING THE NUMBER \\ OF RUSSIANS AND THEIR LIFE EXPECTANCY*
}

\author{
VADIM POKROVSKY, NATALIA LADNAIA, ANASTASIA POKROVSKAYA
}

\begin{abstract}
The spread of the human immunodeficiency virus (HIV), an infection which is life-long and after a few years leads to the development of the deadly acquired immune deficiency syndrome (AIDS), has led to a pandemic of HIV/AIDS affecting the size and life expectancy of the world's population. The article presents data on the incidence of HIV infection and related mortality in the Russian Federation collected and systematized by the authors. In Russia, around 100,000 new cases of HIV are registered annually. The total number has reached 1 million, with the share of AIDS-related deaths relentlessly approaching $1 \%$ of total mortality from all causes, and in the 30-39 age group exceeding 5\%. HIV represents nearly 50\% of all deaths from infectious diseases, and is causing an overall growth in the number of such diseases. There is a direct threat of a further increase in HIV/AIDS-related deaths, as HIV-infected Russians comprise $1 \%$ of Russia's population aged 15-49. The group most affected by HIV are those aged 35-39: $\%$ of them are living with HIV. In the 30-34 age group, the proportion of persons with HIV is approaching 2\%, and in the 40-44 age group it exceeds $1 \%$. The growing proportion of heterosexual transmissions of HIV and the increasing number of HIV-infected women are alarming signs of the HIV epidemic's spillover from intravenous drug users into the general population, making the economic impact of the epidemic even worse. It is necessary to prevent further losses in the most productive part of the population by introducing more efficient HIV prevention strategies and expanding access to treatment of people living with HIV.
\end{abstract}

Key words: HIV, age, incidence, prevalence, ways of transmission, mortality, AIDS.

Infectious diseases still remain an important factor limiting people's life expectancy and numbers. The constant detection of new pathogens, which are spreading faster due to the development of the global market, the evolution of microorganisms under the influence of expanding human activity, and the development of resistance of microorganisms to antibiotics all give grounds to assume an increase in the role of infections in demographic processes, while the discovery of a connection between somatic diseases (gastric ulcer, lymphoma, etc.) and infectious agents suggests the need for a certain rethinking of the concept of the "epidemiological transition" in demographic processes.

\footnotetext{
VAdim Pokrovsky (pokrovsky.vad@yandex.ru), CENTRAl RESEARCH InSTITUTE of EPIDEMiology, Russian FEDERAl SERVICE For Surveillance on CONSUMER Rights Protection ANd Human WELlbeing (ROSPOTREBNADZOR), RUSSIA.

Natalia N Ladnaia, Central Research Institute of Epidemiology, Russian Federal Service for Surveillance ON CONSUMER Rights PROTECTION AND HUMAN WELlBEING (ROSPOTREBNADZOR), RUSSIA.

Anastasia Pokrovskaya, Central Research Institute of Epidemiology, Russian Federal Service for SuRVEILLANCE ON CONSUMER RightS PROTECTION AND HUMAN WELlBEING (ROSPOTREBNADZOR), RusSiA.

* The original aRticle in Russian WAS PUblished in DEMographic REVIEW IN 2017, 4(1), 65-82. DOI: //DOI.ORG/10.17323/DEMREVIEW.V4I1.6988.
} 
Some time ago, a classification of infection groups according to their impact on demographic indicators was proposed [Pokrovsky 2004a; 2007]. Infections differ in different levels of mortality and / or affect different age groups of the population, and, accordingly, reduce life expectancy to differing degrees. One group of infections, having little effect on life expectancy, reduces reproductive capacity (infectious parotitis, sexually transmitted infections - STIs) and fertility. Another group of infections (rubella, Zika) does not particularly affect life expectancy and reproductive capacity, but provokes the appearance of offspring with disabilities, affecting the population size of the following generation. Another classification system singles out infectious diseases which tend to last a lifetime and eventually lead to fatal complications (tuberculosis, viral hepatitis C), but which manifest their symptoms long after infection, thus making it easier for them to spread unnoticed.

The infection caused by the human immunodeficiency virus (HIV), which leads to the development of the fatal syndrome of acquired immune deficiency (AIDS), combines the worst traits of all these groups: it causes premature deaths, reduces fecundity and fertility, often leads to the birth of quite unhealthy children, lasts a lifetime and manifests itself late, making its spread hard to control.

Concerns have been expressed repeatedly about the danger of a large-scale HIV epidemic developing in Russia [Pokrovsky 2004b; 2007]. At the same time, demographers have suggested that "it seems mortality from AIDS will also become perceptible" [Demographic modernization ... 2006: 369]. However, the view of some of our opponents on the possibility of an HIV/AIDS epidemic developing in Russia has been "much more conservative", based on age trends - the likely reduction in the percentage of young people, who are most vulnerable to HIV, among the general population and the belief that "the presence of a relatively large number of older people helps to strengthen social control "[Denisov, Sakevich 2004: 76, 85].

The purpose of this article is to compare statistical data on the demographic aspects of the HIV epidemic in Russia with a view to assessing the degree of the HIV/AIDS threat to the country's population.

\section{THE HIV/AIDS PANDEMIC AND DEMOGRAPHIC PROCESSES}

The HIV pandemic in its impact on the demographic situation can be compared to the two world wars. In the 35 years from the time of its discovery to the end of 2015, it affected more than 78 million people and claimed 35-40 million lives. In 2015 alone there were 2.1 million HIV-infected people in the world and 1.1 million people died of AIDS [UNAIDS 2016]. Despite advances in the treatment of the disease, these losses will continue to grow for a long time.

The spread of HIV/AIDS directly lowers the life expectancy of the population, reduces its numbers due to the premature death of men and women of childbearing age, increases infant mortality, and moreover reduces the reproductive function and the number of deliveries in infected women. HIV/AIDS also has economic consequences. By reducing the size of the able-bodied population, the epidemic worsens the overall economic indicators, and is also associated with an increase in the number of people unable to work and requiring social support: people with disabilities and children left orphans after the death of their parents. Medical and social care for 
people with HIV infection diverts significant resources from other areas of health, which increases the risk of premature death from other diseases.

In just 30 years, HIV has spread throughout the globe, despite the fact that the virus is naturally transmitted from person to person in only a few ways: through sexual intercourse and from the mother to the fetus, as well as from the parenteral passage of an HIV-infected person's tissues into the body of a healthy one (blood transfusion, injections with the same syringe, etc.). HIV infection is life-long. There are no recorded cases of complete recovery, that is, of a person getting rid of the virus. Life expectancy after HIV infection can exceed 20 years, and there are no external signs of the disease, which makes it possible for HIV to spread imperceptibly. The rapid spread of HIV has also been aided by the ease of modern travel, including for people with HIV.

In 2010-2012, HIV/AIDS was the $6^{\text {th }}$ leading cause of death in the world. The highest level of mortality from HIV infection was observed in low-income countries, where, in terms of the number of deaths, HIV/AIDS ranked second after infections of the upper respiratory tract. In 2015, HIV/AIDS was no longer among the top ten causes of death worldwide, but in low-income countries ranked $5^{\text {th }}$ by the number of deaths per 100,000 inhabitants [WHO 2017].

The most dramatic scales of the HIV/AIDS epidemic have been reached in the economically developed South Africa, where a great role has been played by migration links with Central Africa and the seasonal movement of workers within the country. UNAIDS estimated that in 2015, 19.2\% of South Africans aged 15 to 49 were living with HIV [2015]; 162,500 deaths, or $30.5 \%$ of the country's total, were from HIV/AIDS [Statistics South Africa 2016].

The annual HIV/AIDS mortality rate in some countries has been reduced by the massive use of a combination of special anti-HIV antiretroviral drugs in a technique called highly active antiretroviral therapy (ART), which was first proposed in the late 1990s. Thanks to ART, in the United States several times fewer people died directly of AIDS in 2014 than in 1995, although the total number of HIV-infected Americans increased during this time period [CDC 2016].

ART can theoretically extend the life of HIV-infected people to a country's average life expectancy [May et al. 2014]. However, according to one of the cohort studies completed in 2011, the life expectancy of Americans infected with HIV at the age of 20 was 13 years shorter than that of their uninfected peers [Marcus et al. 2016]. According to British researchers [Croxford et al. 2016], in the UK the HIV-positive population has a six times higher risk of death than the general population. The difference in the risk of premature death is largely due to the fact that some of the cases of HIV infection are detected only after the onset of AIDS, when the effectiveness of treatment is not so high. In addition, the desired effect of treatment is achieved only in the case of strict adherence to treatment: the regular taking of several (3-4) drugs, which is expected to be carried out for life. A constant problem is the toxicity of drugs used in ART and the specifics of their interaction with the treatment of other diseases. The significance of this latter problem increases with the age of the HIV-infected person being treated. In the case of non-adherence to the ART regimen, forms of HIV resistant to drugs arise and spread, requiring the transition to other drugs. Thus, the large-scale use of ART is a rather complex exercise that requires of public healthcare not only great expenditures, but also good organization of medical care. 
In recent years, it has been shown that an HIV-infected person who receives ART is less infectious, and in particular that women receiving the treatment give birth to children uninfected by HIV. The likelihood of HIV transmission is also reduced when antiretroviral drugs are taken by uninfected people at risk of infection, such as sexual partners of HIV-positive individuals. The widespread use of these drugs for therapeutic and preventive purposes is the basis of the modern strategy for combating HIV/AIDS, called "treatment as prevention" [WHO 2013; UNAIDS 2015]. It is assumed that, if the strategy is fully successful, HIV transmission will be significantly reduced, all previously HIV-infected individuals will receive ART before they die, and after they all die, the pandemic will stop. Thus, the demographic losses from HIV/AIDS will be minimized. A major obstacle to the implementation of this strategy is the high cost of antiretroviral drugs. In order to overcome this barrier, the production of cheap copies of original drugs, so-called generics, is being set up for the inhabitants of developing countries, but the widespread use of such drugs on a pandemic scale remains costly, and most poor countries receive them through international funds. Since generics are copies of drugs whose patents have expired, their use implies a certain lag in the quality of the treatment provided. Currently, the "treatment as prevention" strategy, because of its high cost, has been fully adopted by only a few rich countries with a developed healthcare system, while the rest are trying, as far as possible, to increase the coverage of the HIV-positive population by ART.

Critics of the strategy believe it too difficult to organize testing of the population in such a way as to identify all people living with HIV and those at risk of infection, provide them with medicines and organize control over the effectiveness of the use of medicines. For this reason, preventive measures such as educating the population about HIV-safe behavior and special programs for people who use drugs intravenously (such as syringe exchange, etc.) have not lost their relevance.

To plan effective anti-HIV/AIDS measures, it is necessary to determine the current stage of development of the HIV epidemic in Russia and the degree of harm it is causing and could cause in the future.

\section{THE DEVELOPMENT OF THE HIV/AIDS EPIDEMIC IN RUSSIA}

\section{Materials and methods}

This article publishes data, processed and analyzed by us, on the incidence of HIV infection for the period from 1987 to 2016, which, on instructions of Rospotrebnadzor, were gathered by the Federal Scientific and Methodological Center for AIDS Prevention and Control of the Central Epidemiological Scientific Research Institute of Rospotrebnadzor (Russian Agency for Health and Consumer Rights). All organizations testing people for HIV are required to inform Rospotrebnadzor of the number of tests conducted and every case of detection of an HIV-infected person, as well as to report data on risk factors for HIV infection from persons identified as HIVpositive and on their deaths [Rospotrebnadzor 2011]. We estimated the number of HIV-infected people in Russia using the Workbook method to estimate the prevalence of HIV in low level or concentrated epidemics [UNAIDS 2007]. 


\section{The incidence of HIV infection}

The total number of Russians infected with HIV registered by Rospotrebnadzor in the Russian Federation as of December 31, 2016 came to 1,114,815 people (according to preliminary data). Of them, 243,863 HIV-positive Russians died from various causes, that is, on this date there were 870,952 HIV-positive Russians living in Russia with an established HIV diagnosis. The dynamics of the number of registered HIV-positive citizens of Russia and the number of their deaths are reflected in Figure 1.

The number of living HIV-infected people, including those whose HIV infection has not yet been diagnosed due to the peculiarities of the disease, must significantly exceed this figure. According to calculations made using the [UNAIDS 2007] method, which is often used to compare the HIV incidence of the population of different countries, the total number of Russian citizens living with HIV in 2015 reached 1.3-1.4 million. Determining the number of HIV-infected individuals more precisely is difficult, not only because of shortcomings in the methods, but also because the number of people who use drugs intravenously is imprecise [Research Institute ... 2016].

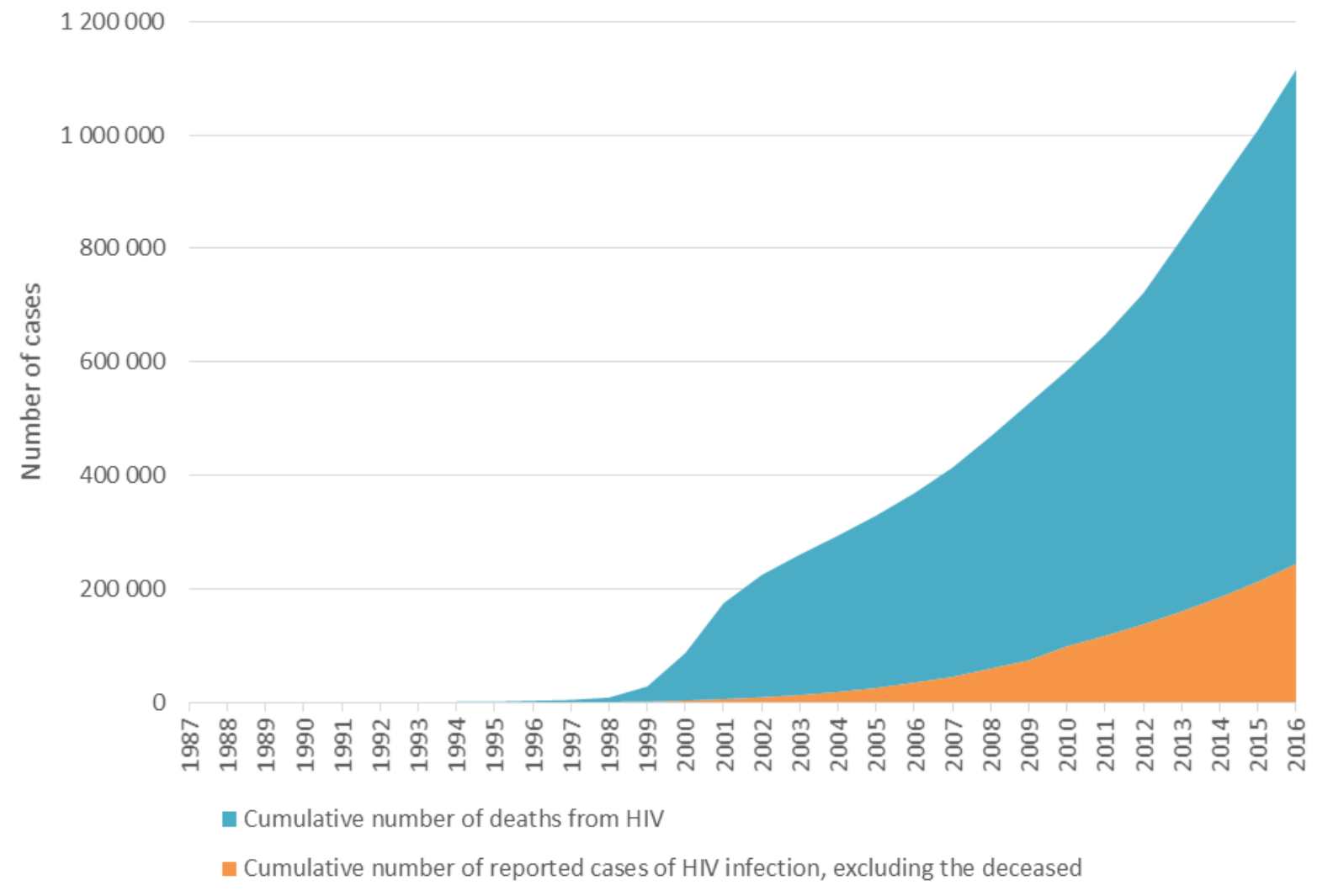

Figure 1. Cumulative number of reported cases of HIV infection among Russian citizens from 1987 to 2016

The term "morbidity" with regard to HIV infection is conditional, since the current testing system in Russia, which involves systematic testing for antibodies to HIV of certain groups of the population, identifies HIV-infected persons at different stages of the disease, i.e. at any time from 2-3 weeks from HIV infection until death. The recording of cases of AIDS of course characterizes the incidence of the last stage of HIV infection, but the collection of this information is not of great 
practical importance, since it basically illustrates the degree of failure in the organization of treatment aimed at preventing the development of AIDS.

The structure of population groups recommended for testing for antibodies to HIV and the number of representatives of these groups who are tested change all the time, therefore, the result of such testing would probably best be called the "detectability" of cases of HIV infection. Data on the number of annual blood tests of the population of the Russian Federation for antibodies to HIV, the detection of which is a reliable sign of HIV infection, and the frequency of detection of HIV infections are shown in Figure 2.

As can be seen from Figure 2, the frequency of newly detected cases of HIV infection increased faster than did the number of tests, which indicates an increase in the incidence of HIVpositive individuals among the population, especially since cases of repeated detection of antibodies in the same person are not included in these results. To put it simply, the data in Figure 2 indicate the continuing spread of HIV infection.

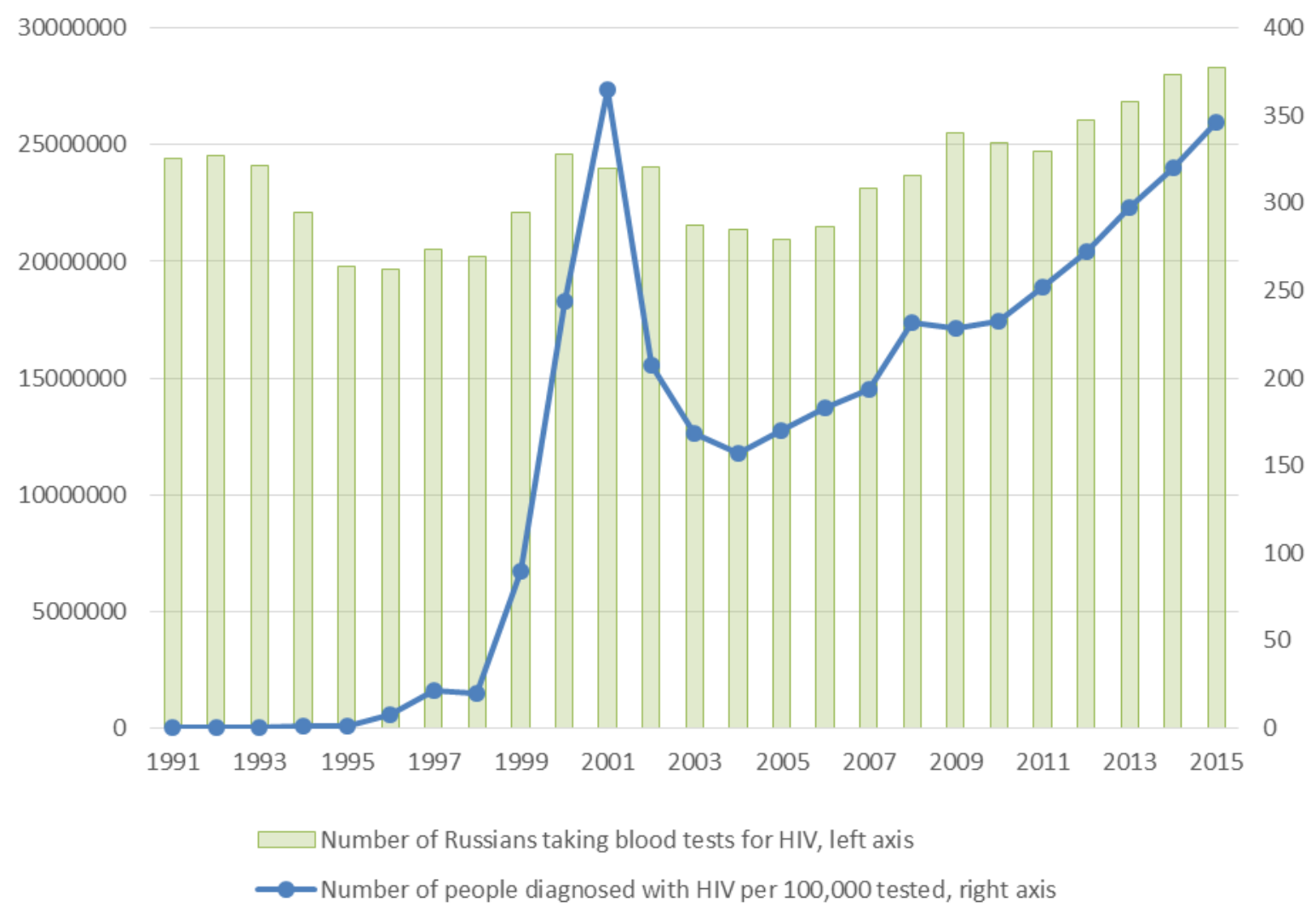

Figure 2. Results of testing for HIV in the Russian Federation in 1991-2016

Note. Columns reflect the number of blood tests of citizens for antibodies to HIV; the line characterizes the change in the number of identified HIV-positive people per 100,000 blood tests in the year of observation.

\section{The prevalence of HIV infection}

Because of the long-term course of HIV infection, in terms of assessing the epidemic situation, of greater importance than detectability is prevalence, an indicator that determines the number of living HIV-positive persons relative to the number of people living in a given area. The prevalence 
indicator is obtained by subtracting from the number of HIV-infected persons the number of infected persons who have died.

At the end of 2016, the HIV prevalence of the entire Russian population, based on the existence of 870,952 HIV-positive people, was 594.3 per 100,000 persons $(0.6 \%$ of the total population). In international practice, the definition of HIV prevalence uses the estimated number of live HIV-infected people per 100,000 persons aged 15 to 49, due to the predominant role of sexual contact in HIV transmission. This indicator for Russia was $1.1 \%$ at the end of 2015 . If we use our estimated number of Russians living with HIV, it reached 1.8\%-2.0\% of the population aged 15-49 in 2015. Figure 3 shows the structure of HIV infection in different age groups of the population of the Russian Federation.

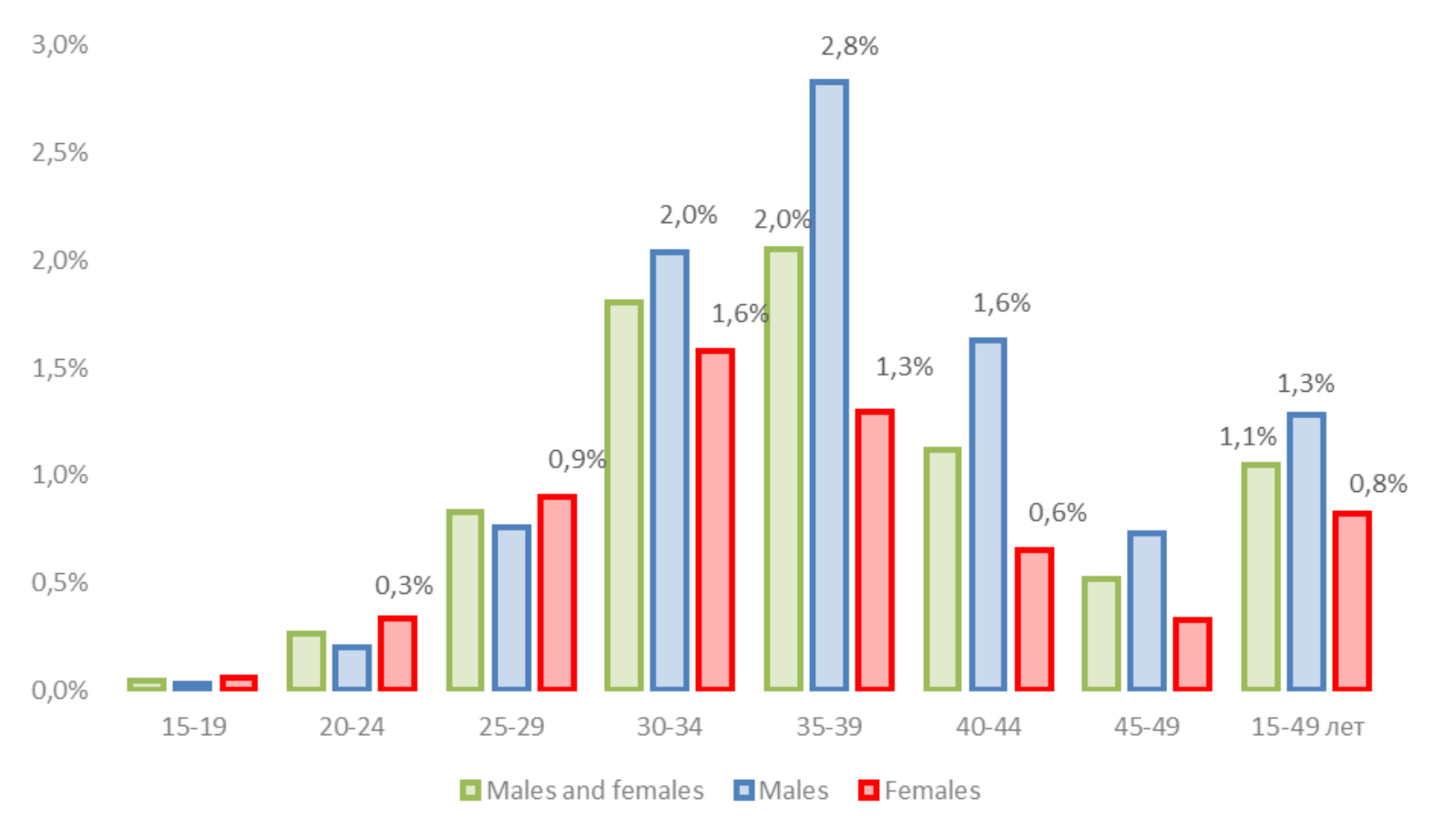

Figure 3. Percentage of HIV-positive persons in different age groups of men and women living in the Russian Federation, 2016

The highest level of prevalence is observed in the group aged 30-39 years. This is due to the fact that HIV infection is lifelong and the risk of acquiring HIV increases with age.

The diagram in Figure 4 shows that the age of HIV-infected persons by year of diagnosing is gradually increasing.

On the one hand, this observation could suggest an increase in the lifespan of HIV-positive persons, but this increase may not in fact be occurring, since AIDS develops faster in older patients. This observation requires changes in how the system of treatment is organized: the older the age group, the more important it is to begin treatment of HIV infection early, as well as to make adjustments which take into account the treatment of diseases characteristic of older ages. At present, there is a clear correlation between the progression of HIV infection and risks of cardiovascular diseases associated with ART. 


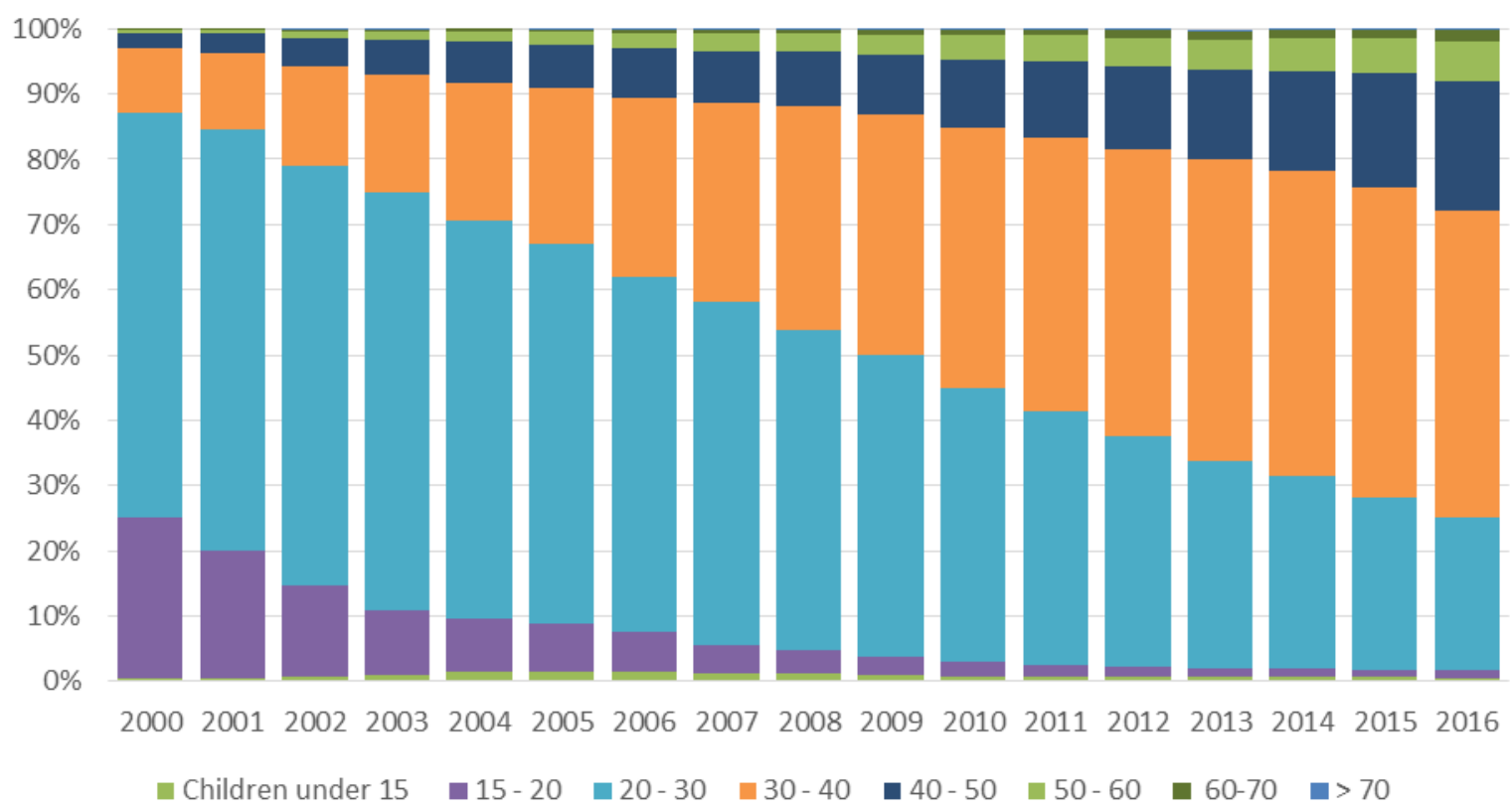

Figure 4. Distribution of new HIV infections by age at the time of detection in 2000-2016

Over time, the sex ratio among individuals identified as HIV-positive has changed (Figure 5).

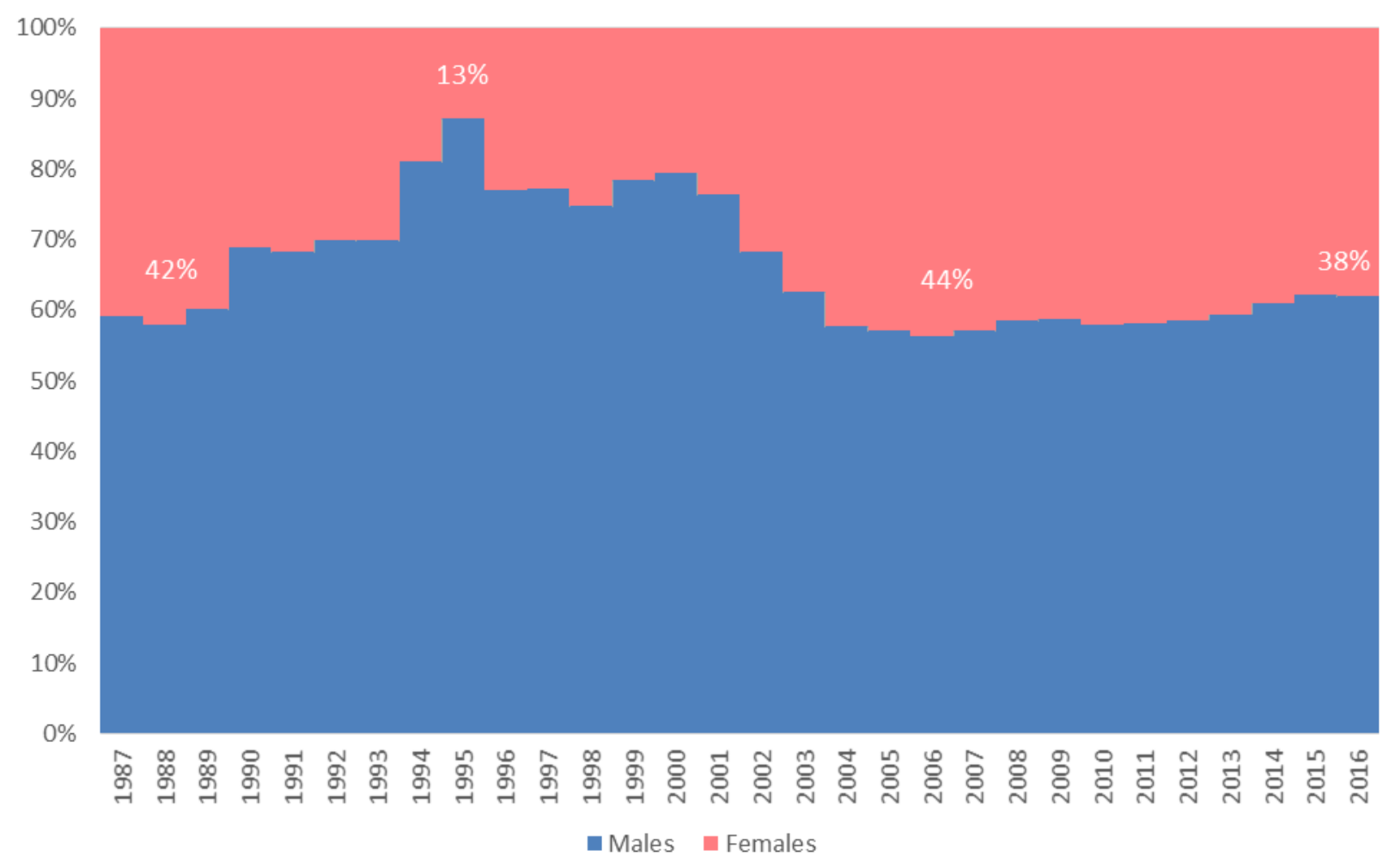

Figure 5. Distribution of HIV-infected persons in Russia in 1987 - 2016 by sex and year of detection

One can attempt to explain both the "aging" of persons diagnosed with HIV and the increase in the proportion of women among them in several ways. It is highly probable that these 
trends are related to changes in the epidemiological situation. Figure 6 shows the changing role of different modes of HIV transmission among the Russian population. At the turn of 2000, the chief mode of infection was intravenous drug use, which explains the overwhelming predominance of men among persons identified as HIV-positive in this period (Figure 5), as men use drugs more often than women [Scientific Research Institute ... 2016]. Since 2002, the proportion of sexually transmitted infections has increased, mainly during sex between men and women. Because in heterosexual transmission both sexes participate, this trend reflects a marked increase in the proportion of women in the 2000s. However, in 2013-2016 the proportion of women declined slightly, which may be due to an increase in HIV transmission during sexual intercourse between men who hide their homosexuality and report heterosexual relationships.

The increase in the age of newly diagnosed HIV-infected persons is partly due to the increase in the age of intravenous drug users. Narcologists note that "over the past 5 years, injecting drug users have been seeking treatment for the first time in their lives at an older age, and there are fewer women among them" [Scientific Research Institute ... 2016]. The authors report a "decrease in the proportion of adolescents (from 1.7 to $0.8 \%$ ) and young people aged 18-19 (from 6.0 to $2.1 \%$ ), a consistently high proportion of the age group of 20-39 years (86- 88\%) and an increase in the proportion of patients aged 40-59 years (from 5.9 to $10.4 \%$ )." It is known that in the USA heroin is used mainly by people over 20 years of age [U.S. Department ... 2014].

The data of narcologists largely coincide with our data on the distribution of HIV-positive persons in different age groups (Figure 3). At the same time, it is necessary to take into account that a drug user can become infected with HIV at an indeterminate time after the first intravenous injection. The longer a drug is used, the greater the likelihood of HIV infection.

Judging from the data in Figure 3, HIV infection occurs most commonly in the group of men aged 35-39 years (2.8\% members of this age group), most likely because drug users in this group have been using drugs for a very long time. In groups under age 30, the percentage of infected women is higher than that of their male peers, which indicates a predominance of sexual transmission of infection at younger ages. This is probably due to the fact that, in cases of irregular sexual contacts, men are often older than women and belong precisely to those age groups in which HIV is the most common.

In general, the graphs in Figures 3-5 show just how serious HIV infection is among the most able-bodied part of the population, those aged 30-40 who have already completed their vocational training. The study "Portrait of a patient living with HIV" [Pokrovskaya et al., 2016] showed that $68.6 \%$ of HIV-positive people visiting AIDS centers had full or part-time jobs. At the same time, $8.3 \%$ of women did not work, as they were temporarily on maternity leave. 


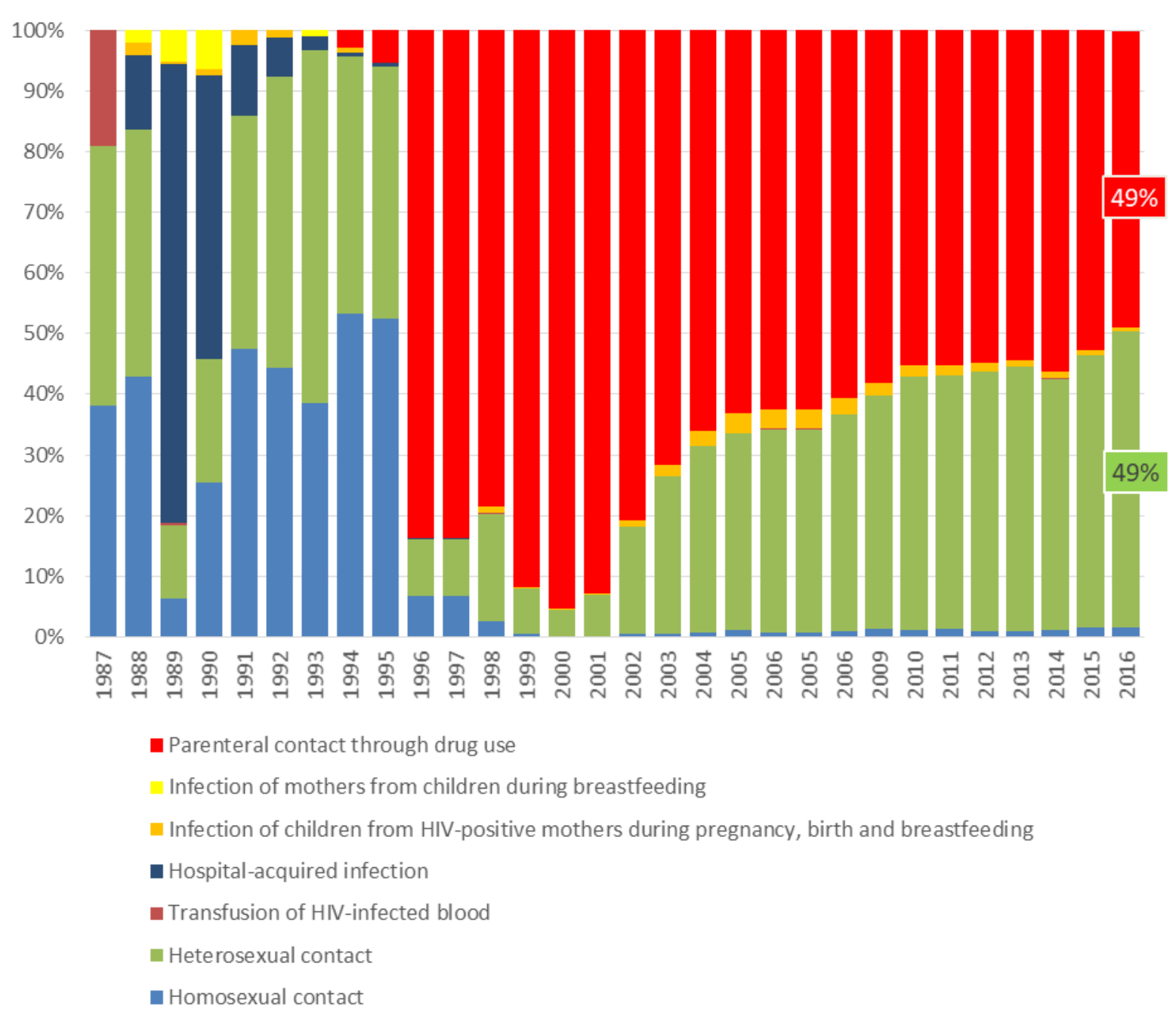

Figure 6. Distribution of HIV-infected persons in Russia by the main known risk factors for infection from 1987 to 2016

\section{Mortality from HIV infection}

Previous studies have shown that, without ART, the median lifespan of HIV-infected Russians from the time of infection to death was 141.6 months (11.8 years). The average age of AIDS patients at the time of death (aged 16 to 76 years) was 34.3 years, the median age was 32.5 years [Pokrovskaya et al., 2014]. Therefore, we expected to see the increase in the incidence of HIV infection followed by an increase in mortality rates. At the same time, the use of highly active ART, which began in Russia on a large scale in 2007, should have led to an increase in the life expectancy of HIV-infected people and a reduction in the number of deaths at a young age.

Figure 1 shows a steady increase in the cumulative number of deceased HIV-infected citizens of Russia, which by the end of 2016 (after 30 years of observation) had reached 243,863, with the number of deaths increasing every year. This increase may be due to an overall rise in the number of HIV-infected individuals, or may have only an indirect relationship with HIV (e.g., suicide).

The growing danger of HIV/AIDS is most evident in the change in the mortality rate of Russians from "the disease caused by the human immunodeficiency virus," which increased from 
1.1 (per 100,000 persons) in 2005 to 8.7 in 2014, while the overall mortality rate from infections decreased from 27.2 to 22.3 , probably due to a decrease in mortality from tuberculosis from 22.5 to 10.0 [Rosstat 2015: 150]. Given the increase in the number of deaths of HIV-infected people, there is no doubt that in 2016 the mortality rate from HIV infection increased even more.

According to Rosstat [Rosstat 2016], HIV infection in 2014 claimed the lives of 12,540 Russians, and in 2015 - 15,520. Those who died of HIV infection in 2015 accounted for $45.1 \%$ of all deaths from "some infectious diseases "(34 372). The losses from HIV infection in 2015 for the first time exceeded the losses from tuberculosis $(13,484)$. In Moscow, "it is now HIV that makes the main contribution to mortality from infectious and parasitic diseases (in 2014, 50\% for men and 56\% for women)" [Andreev, Kvasha, Kharkov 2016: 69]. The increase in the number of deaths from HIV caused the overall increase in the number of deaths from infectious diseases in 2015, despite the decrease in the number of deaths from tuberculosis. In 2015, 34,372 Russians died of "some infectious diseases" at working age, whereas in 2013 the number was 31,807, and in 2014 $-32,103$ [Rosstat 2016]. Judging by the increase in the number of deaths from HIV infection, ART in Russia is still not being used effectively.

Deaths due to HIV infection in 2015 amounted to $0.81 \%$ of all deaths of Russians [Rosstat 2016]. This figure seems insignificant - if we do not take into account that HIV infection is a new, recently unknown cause of death, often occurring at a relatively young age. In 2014, according to official data [Rosstat 2015], 98,953 Russians died between the ages of 30 and 39, of whom, according to our data, 11,396 - i.e. $11.5 \%$ of all deaths in this age group - had HIV. Given that Russian citizens aged 30-39 are most affected by HIV (Figures 3 and 4), it can be argued that HIV infection has become a significant factor in reducing the number of Russians and shortening their life expectancy.

Judging by the increase in the incidence rate (Figure 1) and the level of the Russian population's exposure to HIV infection (Figure 3), its contribution to premature mortality of Russians will increase steadily unless the further spread of HIV is stopped and the continued and effective use of ART is not organized.

\section{The influence of HIV infection on reproduction}

The proportion of women among HIV-infected Russians is $40 \%$ or more (Figure 5), which is directly related to fertility. The HIV infection of a large number of women (more than 410,000) cannot but affect the reproduction, if only because of the possible death of these women in childbearing age. One study [Pokrovskaya et al., 2014] showed that women diagnosed with AIDS who did not receive ART died at a younger age (mean age of men - 34.8, median - 33 years; mean age of women - 32.9, median - 31 years). In another study [Pokrovskaya et al., 2016], it was noted that at the time of the study HIV-infected women had fewer children than the average woman in the Russian Federation. Currently, ART and other measures that significantly reduce the risk of HIV transmission from the mother to a future child can be used with high efficiency. However, these techniques require the continued use of antiretroviral drugs under the regular supervision of doctors during pregnancy. Due to the fact that in Russia some HIV-infected women also use drugs, these requirements are not always strictly followed by them. For this reason, despite the fact that the importance of mother-to-child transmission of HIV is decreasing (Figure 5), about 400 children every year in Russia are infected by mothers during pregnancy and childbirth or breastfeeding, and 
in the future will need ART to survive. Some optimism is inspired only by the fact that the use of ART can prolong their life to childbearing age and ensure the birth of HIV-free offspring.

\section{The effect of migration on the spread of HIV}

HIV was brought to Russia from abroad by various travelers 20-30 years ago, but at present the number of infected foreigners diagnosed in Russia is insignificant relative to the number of HIVinfected Russians, especially since most of them are deported from Russia. During the whole period of observation, 29,625 foreigners with HIV infection were registered in Russia, including 1,736 in 2016. Therefore, there is no reason to believe that foreigners currently have a significant impact on the spread of HIV in Russia. More important is internal migration, which results in the spread of HIV throughout the entire country.

\section{Discussion}

While the problem of HIV/AIDS in Russia only recently attracted any particular attention from demographers, its role in demographic processes has gradually increased to a noticeable level. The data cited point to the continuing spread of HIV in Russia, leading to an increase in the incidence and population burden of HIV infection, and then to an increase in deaths from AIDS among the most active age groups of the population. From this it follows that the measures taken to counteract HIV/AIDS are still insufficient to overcome the consequences of the epidemic, which are harmful to the demographic situation in Russia.

Developing countries too can successfully fight HIV infection. A good illustration of this is Thailand (population 68 million people), where the number of new cases decreased from 152,000 in 1992 to 7,000 in 2015. The annual cost of HIV/AIDS programs in Thailand is about 300 million US dollars, which is close to similar expenditures of the federal budget of the Russian Federation in 2016, but twice as high per capita. These programs provide $65 \%$ of HIV-positive Thai people with ART [HIV and AIDS ... 2015]. However, as the well-known American philosopher F. Fukuyama wrote, "although a significant part of the problems of the fight against AIDS is a resource issue, another important aspect is the government's ability to implement health programs" [Fukuyama 2006: 6].

\section{CONCLUSION}

Rapid growth rates of new HIV infections in Russia, together with a high prevalence accompanied by a significant increase in AIDS deaths in the 30-40 age group, suggest that further development of the HIV/AIDS epidemic could worsen the demographic situation in Russia and adversely affect the economic situation of the country.

To prevent new HIV infections in Russia, it is necessary to introduce more effective HIV prevention programs and to improve and expand HIV treatment programs to increase the life expectancy of HIV-positive Russians. There is also a need for more in-depth studies of the social, psychological and demographic dimensions of the spread of HIV/AIDS. 


\section{REFERENCES}

Andreev E.M., E.A. Kvasha, T.L. Kharkova (2016). Smertnost' v Moskve i drugikh megapolisakh mira: skhodstva i razlichiya [Mortality in Moscow and other megacities and differences] // Demograficheskoe obozrenie [Demographic review]. 3(3): 39-79.

VOZ [WHO] (2013). Vsemirnaya organizatsiya zdravookhraneniya [World health organization]. Svodnoe rukovodstvo po ispol'zovaniyu antiretrovirusnykh preparatov dlya lecheniya i profilaktiki VICh-infektsii [Consolidated guidelines on the use of antiretroviral drugs for treating and preventing HIV infection]. URL: http://www.euro.who.int/_data/assets/pdf_file/0006/248298/Consolidated-GuidelinesRus.pdf (accessed 05.02.2017).

VOZ [WHO] (2014). Vsemirnaya organizatsiya zdravookhraneniya [World health organization]. 10 vedushchikh prichin smerti v mire. Informatsionnyy byulleten' [The top 10 causes of death worldwide]. 310. URL: http://who.int/mediacentre/factsheets/fs310/ru (accessed 05.02.2017).

Demograficheskaya modernizatsiya Rossii, 1900-2000 [Demographic modernization in Russia, 1900-2000] (2006) / A.G.Vishnevsky, ed. Moscow: Novoe izdatel'stvo. 601 p.

Denisov B.P., V.I. Sakevich (2004). Dinamika epidemii VICh/SPID [The dynamics of the HIV] // Sotsiologicheskie issledovaniya [Sociological Studies]. 1: 75-85.

Nauchno-issledovatel'skiy institut narkologii [Research institute of narcology] (2016). Osnovnye pokazateli deyatel'nosti narkologicheskoy sluzhby v Rossiyskoy Federatsii v 2014-2015 godakh [Key indicators of substance abuse services in the Russian Federation in 2014-2015]. URL: http://nncn.ru/2_732.html (accessed 05.02.2017).

Pokrovskaya A.V., N.V. Kozyrina, Yu.Sh.Gushchina., O.G. Yurin, Z.K.Suvorova, V.V. Pokrovsky (2016). Sotsial'no-demograficheskiy portret patsienta, zhivushchego s VICh i poseshchayushchego tsentry SPID v Rossii [Socio-demographic portrait of patients living with HIV who visiting AIDS centers in Russia] // Terapevticheskiy arkhiv [Therapeutic Archives]. 88(11): 12-16.

Pokrovskaya A.V., A.A. Popova, N.N. Ladnaia , O.G. Yurin (2014). Prodolzhitel'nost' techeniya VICh-infektsii i vliyayushchie na nee faktory [The duration of an HIV infection course and its influencing factors] // Terapevticheskiy arkhiv [Therapeutic Archives]. 86 (11): 20-23.

Pokrovsky V.V. (2004a). VICh-infektsiya v Rossii: prognoz [HIV infection in Russia: prognosis] // Voprosy virusologi [Questions of Virology]. 49(3): 31-35.

Pokrovsky V.V. (2004b). Sotsial'no znachimye infektsii v XXI veke [Socially important infections in the XXI century] // Narodonaselenie [Population]. 3(25): 93-96.

Pokrovsky V.V. (2007). Infektsii i demografiya [Infections and demography] // Terapevticheskiy arkhiv [Therapeutic Archives]. 79(11): 5-9.

Rospotrebnadzor [Rospotrebnadzor] (2011). Sanitarno-epidemiologicheskie pravila SP 3.1.5.2826-10 [Sanitary rules SP 3.1.5.2826-10]. URL: http://rospotrebnadzor.ru (accessed 01.02.2017).

Rosstat [Rosstat] (2015). Demograficheskiy ezhegodnik Rossii, 2015: Statisticheskiy sbornik [The Demographic Yearbook of Russia, 2015: Statistical Handbook]. URL: http://www.gks.ru/free_doc/doc_2015/demo15.pdf (accessed 02.02.2017). 
Rosstat [Rosstat] (2016). Smertnost' naseleniya po prichinam smerti v 2015 godu (Obnovlenie ot 26.05.2016) [Mortality by cause of death in 2015 (Updated on 05.26.2016)]. URL: http://gks.ru (accessed 01.02.2017).

Fukuyama F. (2006). Sil'noe gosudarstvo: Upravlenie i mirovoy poryadok v XXI veke [State Building: Governance and world order in the 21st century]. Moscow: AST: AST. MOSKVA: KHRANITEL'.

YuNEYDS [UNAIDS] (2016). Global'naya statistika - 2015 g. Informatsionnyy byulleten' [Global statistics - 2015. Informational bulletin]. URL: http://unaids.org (accessed 02.02.2017).

CDC (2016). Centers for Diseases Control and Prevention. HIV/AIDS. URL: http://cdc.gov/hiv/statistics/overview/ataglance.html (accessed 01.02.2017).

Croxford S., A. Kitching, S. Desai et al. (2016). Mortality and causes of death in people diagnosed with HIV in the era of highly active antiretroviral therapy compared with the general population: an analysis of a national observational cohort // Lancet. 2667(16): 3002030022.

HIV and AIDS... (2016). HIV and AIDS data hub for ASIA and Pacific. Key facts on HIV in Asia and the Pacific (2015). URL: http://aidsdatahub.org (accessed 05.02.2017).

Marcus J.L., C.R. Chao, W.A. Leyden, L. Xu et al. (2016). Narrowing the gap in life expectancy for HIV+ compared with HIV- individuals // Conference on Retroviruses and opportunistic infections (CROI) 2016, Boston, abs 54.

May M.T., M. Gompels, V. Delpech, Kh. Porter et al. (2014). Impact on life expectancy of HIV1 positive individuals of CD4+ cell count and viral load response to antiretroviral therapy // AIDS. 28(8): 1193-1202.

Statistics South Africa (2016). Statistical release P0302 «Mid-year population estimates 2015». URL: http://statssa.gov.za (accessed 02.02.2017).

U.S. Department of Justice, Drug Enforcement Administration (2016). National drug threat assessment summary. URL: https://www.hsdl.org/?view\&did=797265 (accessed 02/02/2017).

UNAIDS (2007). Using the workbook method to make HIV/AIDS estimates in countries with low-level or concentrate epidemic. URL: http://data.unaids.org/pub/Manual/2007/workbook_manual_2007_en.pdf (accessed 02/02/2017).

UNAIDS (2015). Strategy 2016-2021. URL: http://www.unaids.org/en/resources/documents/2015/UNAIDS_PCB37_15-18 (accessed 02.02.2017). 